\title{
Penerapan Sistem Pembuktian Terbalik terhadap Tindak Pidana Korupsi
}

(Sebuah Upaya Progresif dalam Pemberantasan Tindak Pidana Korupsi)

\author{
Muwahid \\ IAIN Sunan Ampel Surabaya \\ E-mail: Muwahidizza@gmail.com
}

\begin{abstract}
The main object of this research is the regulation reversal burden of proof system of corruption in Act Number 20 of 2001. This research is a normative legal research, data obtained from primary legal materials that legislation, and secondary legal materials namely, books, journals and law relating to the burden of proof. The technique of data analysis uses content analysis.

The results of research showed, First the reversal burden of proof system in criminal law of corruption stipulated in Article 12B paragraph (1), Article 37, Article 38A and Article 38B of Act Number 20 of 2001 on the eradication of corruption.

Second, the application of reversal burden of proof principle in a criminal act of corruption is a specific provision in the law of criminal procedure, as a way to take war or eradicate of the corruption which is an extra ordinary crime, this provision is evidence of irregularities in the conventional system as was stipulated by the Criminal Code, in this case applies the principle of lex specialis derogat lex generalis.
\end{abstract}

Keywords: Aplication, Reversal Burden of Proof, Corruption.

\section{A. Pendahuluan}

Korupsi merupakan masalah yang besar dan menarik sebagai persoalan hukum, dan menyangkut jenis kejahatan yang rumit penanggulangannya, karena korupsi mengandung aspek yang majemuk dalam kaitanya dengan politik, ekonomi, dan sosial-budaya. Berbagai upaya pemberantasan sejak dulu ternyata tidak mampu mengikis habis kejahatan korupsi.

Tindak pidana korupsi merupakan kejahatan luar biasa (extra ordinary crime), di samping tindak pidana ekonomi lainnya, tindak pidana korupsi juga merupakan kejahatan kerah putih (white collar crime) (Evi Hartanti, 2009: 2) yang dilakukan oleh orangorang yang berdasi. Akibat dari tindak pidana korupsi sangat merugikan keuangan negara dan perkonomian negara. Oleh karena itu upaya penanggulanganya juga harus menggunakan cara-cara yang luar biasa pula.

Tindak pidana atau perbuatan pidana merupakan perbuatan yang oleh aturan hukum pidana dilarang dan diancam dengan pidana barang siapa yang melanggar aturan tersebut. Menurut wujudnya atau sifatnya perbuatan pidana ini adalah perbuatan-perbuatan yang melawan hukum. Tindak pidana korupsi juga merugikan masyarakat, dalam arti bertentangan dengan atau menghambat akan terlaksananya tatanan dalam pergaulan masyarakat yang dianggap baik dan adil (K. Wanjtik Saleh, 1983: 16).

Korupsi sendiri merupakan istilah yang berasal dari bahasa latin "Corruptio atau Corruptus" yang artinya busuk, buruk, bejat, dapat disuap, menyimpang dari kesucian, perkataan menghina atau memfitnah. Dalam perkembangannya kata korupsi diartikan sebagai perbuatan curang dan dapat disuap (Ninik Mariyanti, dalam Andi Hamzah, 1986: 197). Dengan demikian secara harfiah korupsi merupakan perbuatan yang busuk, jahat dan merusak sendi-sendi kehidupan masyarakat.

Tindak pidana korupsi di Indonesia sebagaimana diatur dalam Undang-undang Nomor 31 Tahun 1999 Jo Undang-undang Nomor 20 Tahun 2001 dapat dirumuskan sebagai suatu perbuatan secara melawan hokum yang bermaksud memperkaya diri sendiri atau orang lain secara langsung atau tidak langsung merugikan keuangan negara dan perekonomian negara, atau patut disangka bahwa perbuatan tersebut merugikan keuangan negara atau perekonomian negara (Evi Hartanti, 2009: 17).

Untuk menanggulangi terhadap tindak pidana korupsi sebagaimana di atas dapat dilakukan melalui upaya penal (sarana hukum pidana) (Barda Nawawi Arif, 2000:3). Namun demikian salah satu faktor yang menyebabkan sulitnya mengusut tindak pidana korupsi adalah 
sulitnya menemukan bukti atau membuktikan adanya tindak pidana korupsi. Membuktikan mengandung maksud dan sebuah usaha untuk menyatakan kebenaran atas suatu peristiwa, sehingga dapat diterima oleh akal terhadap kebenaran peristiwa tersebut (Martiman Prodjohamijojo, 1983: 11).

Mengingat semakin merajalelanya tindak pidana korupsi di Indonesia, maka tidak salah jika diterapkan pembuktian terbalik terhadap tindak pidana korupsi. Penerapan pembuktian terbalik ini merupakan penyimpangan dari sistem pembuktian konvensional, dimana yang wajib membuktikan dilakukannya tindak pidana adalah jaksa bukan, bukan terdakwa.

Melalui pembuktian terbalik ini siapapun yang melakukan tindak pidana korupsi berkewajiban memberikan keterangan tentang asal-usul hartanya. Dengan pembuktian terbalik ini, pihak penyidik, baik polisi maupun jaksa penuntut umum tidak perlu susah payah mendapatkan bukti tindak pidana korupsi. Dengan demikian, penerapan pembuktian terbalik ini sebenarnya bisa menimbulkan efek jera terhadap pelaku korupsi, karena koruptor yang harus membuktikan bahwa dirinya tidak bersalah, sehingga apabila ia tidak mampu membuktikan, maka ia dengan sendirinya terbukti telah melakukan tindak pidana korupsi.

Berdasarkan uraian di atas, maka peneliti dapat merumuskan dua masalah penelitian, yang pertama, bagaimanakah pengaturan sistem pembuktian terbalik dalam Undang-undang Nomor 31 Tahun 1999 Jo. Undang-undang Nomor 20 Tahun 2001 tentang Pemberantasan Tindak Pidana Korupsi?, yang kedua, apakah penerapan sistem pembuktian terbalik terhadap tindak pidana korupsi tidak bertentangan dengan ketentuan Kitab Undangundang Hukum Acara Pidana?

\section{B. Metode Penelitian}

Penelitian ini merupakan penelitian yuridis normatif dengan pendekatan perundangundangan (statute approach). dan pendekatan konseptual (conceptual approach) (Petter Mahmud Marzuki, 2005, 93; Johny Ibrahim, 2011: 302). Pendekatan perundang-undangan (statute approach) dilakukan dengan menelaah semua peraturan perundang-undangan dan regulasi yang berkaitan dengan tindak pidana korupsi. Sedangkan pendekatan konseptual (conceptual approach) dilakukan dengan menelaah pandangan-pandangan dan doktrindoktrin yang berkembang dalam ilmu hukum, khususnya hukum pidana, dengan demikian peneliti akan menemukan ide-ide yang melahirkan pengertian-pengertian hukum, konsep-konsep hukum dan asas-asas hukum dalam kaitannya dengan penerapan pembuktian terbalik terhadap tindak pidana korupsi. Dengan pendekatan tersebut, pada akhirnya peneliti bisa menganalisis tentang asas pembuktian terbalik baik dalam pengaturanya dalam peraturan perundang-undangan (Undang-undang Nomor 20 Tahun 2001 jo Undang-undang Nomor 31 Tahun 1999 tentang Pemberantasan Tindak Pidana Korupsi) sekaligus menganalisis implementasi (penerapan) asas pembuktian terbalik dalam kasus tindak pidana korupsi.

Dalam penelitian ini bahan hukum primernya yaitu Undang-undang Nomor 31 Tahun 1999 jo Undang-undang Nomor 20 Tahun 2001 tentang Pemberantasan Tindak Pidana Korupsi; dan Kitab Undang-Undang Hukum Acara Pidana (KUHAP), beserta peraturanperaturan pelaksanaanya. Sedangkan bahan hukum sekundernya diperoleh dari buku, jurnal, jurisprudensi (putusan-putusan hakim), dan artikel yang terkait dengan pembuktian terbalik dalam tindak pidana korupsi.

Metode pengumpulan data dalam penelitian ini menggunakan metode dokumenter (dokumentasi) (Burhan Bungin, 2001: 152). Studi dokumentasi merupakan teknik pengumpulan data yang tidak langsung ditujukan kepada subyek penelitian. Dokumen merupakan bahan tertulis atau benda yang berkaitan dengan suatu peristiwa/aktifitas tertentu (Imam Suprayogo\&Tobroni MS, 2003: 164). Dokumen yang digunakan dalam penelitian ini berupa peraturan perundang-undangan, pendapatpandapat ahli hukum (doktrin), jurnal, dan artikel-artikel yang berkaitan dengan asas pembuktian terbalik.

Teknik analisa data yang digunakan adalah content analysis (tehnik analisis isi), dengan asumsi bahwa analisa selalu menampilkan tiga syarat yaitu obyektifitas, pendekatan sistematis dan generalisasi.

$$
1 .
$$

\section{Hasil Penelitian dan Pembahasan}

Membuktikan mengandung maksud dan usaha untuk menyatakan kebenaran atas suatu peristiwa, sehingga dapat diterima oleh akal terhadap kebenaran peristiwa tersebut (Martiman Projohamijodjo, 2009: 11). Menurut Subekti yang dimaksud dengan membuktikan ialah meyakinkan hakim tentang kebenaran dalil atau dalil-dalil yang 
dikemukakan dalam suatu persengketaan. Dengan demikian, menurut Subekti bahwa pembuktian ini hanyalah diperlukan dalam persengketaan atau perkara di muka Hakim atau Pengadilan (Subekti, 2005: 1).

Sedangkan sistem pembuktian adalah ketentuan tentang bagaimana cara dalam membuktikan dan sandaran dalam menarik kesimpulan tentang terbuktinya apa yang dibuktikan. Pengertian sistem pembuktian yang mengandung isi yang demikian dapat pula disebut dengan teori atau ajaran pembuktian.

Pembuktian tentang benar tidaknya terdakwa melakukan perbuatan yang didakwakan, merupakan bagian yang terpenting acara pidana. Untuk itulah, pembuktian dalam Hukum Acara Pidana bertujuan untuk mencari kebenaran materiil. Hal ini berbeda dengan Hukum Acara Perdata yang hanya mencari kebenaran formil (Subekti, 2005: 9).

Dalam menilai kekuatan pembuktian tersebut dalam hukum pembuktian dikenal beberapa sistem atau teori pembuktian, yaitu; teori pembuktian yang hanya berdasarkan kepada alat-alat pembuktian yang disebut oleh undangundang secara positif (positief wettelijk bewijstheorie); teori pembuktian berdasar keyakinan hakim semata-mata (conviction intime); teori pembuktian berdasar keyakinan hakim dalam batas-batas tertentu atas alasan yang logis (conviction raisonee); dan teori pembuktian berdasar keyakinan hakim yang timbul dari alat-alat bukti dalam undang-undang secara negatif (negatief wettelijk bewijstheori) (Hari Sasangka, 2003:116).

Pertama, teori pembuktian yang hanya berdasarkan kepada alat-alat pembuktian yang disebut oleh undang-undang secara positif (positief wettelijk bewijstheorie). Dalam teori ini undangundang menetapkan macam-macam alat bukti yang dapat dipakai oleh hakim, dan cara-cara bagaimana hakim mempergunakan alat-alat bukti tersebut, serta kekuatan pembuktian dari alat-alat bukti tersebut.

Jika alat-alat bukti sudah dipakai sebagaimana yang ditetapkan oleh undangundang, maka hakim harus menetapkan keadaan sudah terbukti, walaupun hakim mungkin berkeyakinan bahwa yang harus dianggap terbukti itu tidak benar. Sebaliknya jika tidak dipenuhi cara-cara mempergunakan alat bukti meskipun hakim berkeyakinan bahwa keadaan itu benar-benar terjadi, maka keyakinan hakim tersebut harus dikesampingkan (Martiman
Projohamijodjo, 2009: 82). Teori pembuktian secara positif berusaha menyingkirkan semua pertimbangan subyektif hakim secara ketat menurut peraturan-peraturan pembuktian yang keras.

Oleh karena itu menurut D. Simon bahwa system positief wettelijk dipakai pada waktu hukum acara pidana yang bersifat inquisitoir. Dalam hukum acara pidana inquisitoir terdakwa dianggap sebagai obyek pemeriksaan dan hakim merupakan lat pelengkap belaka (Martiman Projohamijodjo, 2009: 82).

M. Yahya Harahap menyatakan bahwa dalam pembuktian menurut undang-undang secara positif, keyakinan hakim tidak ikut ambil bagian dalam membuktikan kesalahan terdakwa. Keyakinan hakim dalam sistem ini tidak berperan dalam menentukan salah atau tidaknya terdakwa. Sistem ini berpedoman pada prinsip pembuktian dengan alat-lat bukti yang ditentukan undang-undang. Untuk menentukan salah atau tidaknya terdakwa semata-mata digantungkan pada alat-alat bukti yang sah. Asal sudah dipenuhi syarat-syarat dan ketentuan pembuktian menurut undang-undang, sudah cukup menentukan kesalahan tanpa mempersolkan keyakinan hakim (M.Yahya Harahap, 2005: 789). Apakah hakim yakin atau tidak tentang kesalahan terdakwa, bukan menjadi masalah. Pokoknya apabila sudah dipenuhi caracara pembuktian dengan alat-alat bukti yang sah menurut undang-undang, hakim tidak lagi menanyakan keyakinan hati nuraninya akan kesalahan terdakwa.

Dalam sistem ini hakim seolah-olah robot pelaksana undang-undang yang tidak memiliki hati nurani. Hati nuraninya seolah-olah tidak ikut hadir dalam menentukan salah atau tidaknya terdakwa. Namun demikian dari satu sisi sistem ini mempunyai kebaikan. Sistem ini benar-benar menuntut hakim, suatu kewajiban mencari dan menemukan kebenaran salah atau tidaknya terdakwa sesuai dengan tata cara pembuktian dengan alat-alat bukti yang telah ditentukan undang-undang. Dalam pemeriksaan perkara, hakim harus melemparkan dan menyampingkan jauh-jauh faktor keyakinanya. Hakim sematamata berdiri tegak pada nilai pembuktian obyektif tanpa mencampur-adukkan hasil pembuktian yang diperoleh di persidangan dengan unsur-unsur subyektif keyakinanya.

Sekali lagi majelis hakim menemukan hasil pembuktian yang obyektif sesuai dengan cara-cara dan alat bukti yang sah menurut undang-undang, mereka tidak perlu lagi bertanya dan menguji hasil pembuktian tersebut dengan 
keyakinannya (M.Yahya Harahap, 2005: 799). Dalam perkembangannya dengan titik tolak aspek negatif dan positif mana yang baik secara teoritis dan praktik dalam sistem pembuktian menurut undang-undang secara positif (positief wettelijke bewijs theorie) sudah tidak pernah diterapkan lagi (Lilik Mulyadi, 2007: 245).

Kedua, teori pembuktian berdasar keyakinan hakim semata-mata (conviction intime). Menurut teori ini terbukti tidaknya suatu perkara pidana hanya didasarkan pada keyakinan hakim semata, dengan tidak terikat pada suatu peraturan. Dalam aliran ini tidak dibutuhkan suatu peraturan tentang pembuktian, segala sesuatu diserahkan kepada kebijaksanaan hakim sehingga hakim dianggap subyektif. Dengan demikian menurut teori ini salah tidaknya terdakwa tergantung sepenuhnya kepada keyakinan hakim belaka, sehingga hakim tidak terikat pada suatu peraturan (conviction intime) (Djoko Sumaryanto, 2009: 87). Namun demikian, dalam pertimbangannya hakim selalu menggunakan pikiran dengan menggunakan logika silogisme yakni dengan premis mayor, premis minor dan konklusi sebagai hasil penarikan konklusi (Martiman Pojohamidjojo, 2009: 81).

Apabila dikaji secara mendalam, maka penerapan sistem pembuktian conviction intime mempunyai bias subyektif, yaitu; dalam sistem pembuktian conviction intime yang menentukan salah tidaknya terdakwa semata-mata ditentukan oleh penilaian hakim. Keyakinan hakimlah yang menentukan terbuktinya kesalahan terdakwa, dari mana hakim menyimpulkan keyakinannya, tidak menjadi masalah dalam sistem ini. Keyakinan boleh diambil dan disimpulkan hakim dari alat-alat bukti yang diperiksanya dalam sidang pengadilan, bisa juga kesimpulan hakim diambil dari pengakuan terdakwa. Dengan cara begitu sudah barang tentu sistem ini mengandung kelemahan, hakim dapat saja menjatuhkan hukuman pada seorang terdakwa atas dasar keyakinannya tanpa didukung dengan alat bukti yang cukup. Sebaliknya hakim leluasa membebaskan terdakwa dari tindak pidana yang dilakukanya walaupun kesalahan terdakwa sudah cukup terbukti dengan alat-alat bukti yang lengkap, selama hakim tidak yakin dengan kesalahan terdakwa (M Yahya Harahap, 2005: 798).

Ketiga, teori pembuktian berdasar keyakinan hakim dalam batas-batas tertentu atas alasan yang logis (conviction raisonee). Teori hukum pembuktian conviction rasionee asasnya identik dengan sistem conviction intime, pada teori pembuktian berdasarkan keuyakinan hakim dalam batas- batas tertentu atas alasan yang logis, keyakinan hakim tetap memegang peranan penting untuk menentukan tentang kesalahan terdakwa, akan tetapi penerapan keyakinan hakim tersebut dilakukan secara selektif dalam arti keyakinan hakim dibatasi dan harus didukung dengan alasanalasan yang jelas dan rasional dalam mengambil keputusan (Djoko Sumaryanto, 2009: 88).

Keempat, teori pembuktian berdasar keyakinan hakim yang timbul dari alat-alat bukti dalam undang-undang secara negatif (negatief wettelijk bewijstheori) (Hari Sasangka, 2003: 16). Menurut teori ini hakim hanya boleh menjatuhkan pidana terhadap terdakwa apabila alat bukti tersebut secara limitatif ditentukan oleh undang-undang dan didukung pula oleh adanya keyakinan hakim terhadap eksistensi alat-alat bukti tersebut. Dengan demikian, dalam memutuskan perkara hakim harus mempertimbangkan alat-alat bukti yang diatur dalam undang-undang ditambah dengan keyakinan hakim. Disebut dengan sistem menurut undang-undang, karena dalam membuktikan harus menurut ketentuan undangundang, baik alat-lat bukti yang digunakan maupun cara mempergunakannya serta syaratsyarat yang harus dipenuhi untuk menyatakan tentang terbuktinya kesalahan terdakwa melakukan tindak pidana yang didakwakan (Adami Chazawi, 2008: 29). Disebut dengan terbatas/negatif, karena dalam melakukan pembuktian untuk menarik kesimpulan tentang terbuktinya kesalahan terdakwa melakukan tindak pidana di samping dengan menggunakan alat-alat bukti yang sah menurut undang-undang juga dibatasi/diperlukan keyakinan hakim. Artinya bila ketiadaan keyakinan hakim, tidak boleh menyatakan sesuatu yang dibuktikan sebagai terbukti, walaupun alat bukti yang dipergunakan telah memenuhi syarat minimal.

Tindak pidana korupsi merupakan kejahatan yang luar biasa (extra ordinary crimes), oleh karena itu diperlukan penanggulangan dari aspek yuridis yang luar biasa (extra ordinary enforcement) dan perangkat hukum yang luar biasa pula (extra ordinary measures). Dari aspek ini salah satu langkah komprehensif yang dapat dilakukan dalam sistem peradilan pidana di Indonesia adalah melalui sistem pembuktian yang lebih memadai yaitu diperlukan adanya pembuktian terbalik atau pembalikan beban pembuktian, atau dalam system Anglo Saxon dan case law dikenal dengan terminologi Reversal Burden of Proof/Shifting Burden of Proof atau dalam 
terminologi sistem hukum Eropa Kontinental Omkering Van Het Bewijslat.

Pada asasnya beban pembuktian terbalik bermula dari sistem pembuktian yang dikenal dari negara yang menganut rumpun Anglo Saxon yang terbatas pada certain cases khususnya terhadap tindak pidana gratifikasi (gratification), atau sebuah pemberian yang berkolerasi dengan suap (bribery), misalnya negara Malaysia yang mengatur gratifikasi dalam The Status of Prevention of Corruption Act (Lilik Mulyadi, 2007: 254). Sistem beban pembuktian terbalik dalam hukum acara pidana korupsi kita, dapat dibaca pada pasal $12 \mathrm{~B}$ ayat (1), jo, 37, 37A, jo 38A dan 38B Undang-undang Nomor 20 Tahun 2001 (Adami Chazawi, 2008: 114).

Pasal 12B menyebutkan:

1. Setiap gratifikasi kepada pegawai negeri atau penyelenggara negara dianggap pemberian suap apabila berhubungan dengan jabatannya dan yang berlawanan denga kewajiban atau tugasnya, dengan ketentuan sebagai berikut:

a. Yang nilainya RP. 10.000.000,-(sepuluh juta rupiah) atau lebih, pembuktian bahwa gratifikasi tersebut bukan merupakan suap dilakukan oleh penerima gratifikasi;

b. Yang nilainya kurang dari 10.000.000,-(sepuluh juta rupiah), pembuktian bahwa gratifikasi tersebut suap dilakukan oleh Penuntut Umum.

2. Pidana bagi pegawai negeri atau penyelenggara negara sebagimana dimaksud dalam ayat (1) adalah pidana seumur hidup atau pidana penjara paling singkat 4 (empat) tahun dan paling lama 20 (dua puluh) tahun, dan pidana denda paling sedikit Rp. 200.000.000,(dua ratus juta rupiah) dan paling banyak Rp. 1.000.000,-(satu milyar rupiah).

Sistem Pembuktian terbalik sebagaimana diatur dalam Pasal 12B Undang-undang Nomor 20 Tahun 2001 tersebut, menentukan terdakwa yang harus membuktikan bahwa gratifikasi yang diterimanya bukan merupakan suap. Dengan demikian, berlaku asas praduga bersalah. Artinya bahwa sesuatu gratifikasi yang diterima pegawai negeri atau penyelenggara negara adalah suap, kecuali ia dapat membuktkan sebaliknya. Sistem pembuktian terbalik ini merupakan pengecualian dari asas praduga tidak bersalah (presumption of innocence), sebagaimana diatur dalam KUHAP. Dalam Pasal 12B ayat (1) disebutkan bahwa setiap gratifikasi kepada pegawai negeri atau penyelenggara negara dianggap pemberian suap, apabila berhubungan dengan jabatanya dan yang berlawanan dengan kewajiban atau tugasnya. Untuk gratifikasi yang nilainya Rp. 10.000.000.(sepuluh juta) atau lebih penerima wajib membuktikannya bahwa pemberian itu bukan sebagai suap (Darwan Prints, 2002: 115).

Apabila dikaji dari perspektif kebijakan formulatif, beban pembuktian terbalik ini dilakukan karena tindak pidana korupsi sebagai ketentuan yang bersifat "premium remedium" dan sekaligus mengandung prevensi khusus. Dengan diterapkannya sistem pembuktian terbalik ini, bergeserlah pembalikan pembuktian dari jaksa penuntut umum kepada terdakwa.

Apabila dilihat dari sujud obyek apa yang harus dibuktikan terdakwa, maka pembuktian terbalik hanya berlaku dan diterapkan pada 2 (dua) obyek pembuktian, yaitu:

Pertama, pada korupsi suap menerima gratifikasi yang nilainya Rp. 10 juta atau lebih (Pasal 12B ayat 1 jo 37 ayat 2 jo 38A). Pembuktian terbalik pada korupsi suap menerima gratifikasi, dimana terdakwa dibebani kewajiban (bukan hak) untuk membuktikan tidak melakukan korupsi menerima gratifikasi, dapat disebut dengan sistem beban pembuktian terbalik murni. Karena obyek yang wajib dibuktikan terdakwa adalah langsung pada unsur-unsur (kebalikannya) tindak pidana yang didakwakan (dalam perkara pokok), yang mengandung akibat hukum langsung pada pembebasan atau sebaliknya pemidanaan terdakwa atau pelepasan dari tuntunan hukum.

Kedua, pada harta benda terdakwa yang belum didakwakan (Pasal 38B jo 37). Kewajiban terdakwa membuktikan terbalik (sebaliknya), yang kedua ini adalah bukan terhadap tindak pidana (unsur-unsurnya) yang didakwakan. Akibat hukum dari harta terdakwa diperoleh dari korupsi atau secara halal, tidak menentukan dipidana atau dibebaskan terdakwa dari dakwaan melakukan korupsi dalam perkara pokok. Melainkan sekedar untuk dapat menjatuhkan pidana perampasan barang dalam hal terdakwa tidak berhasil membuktikan harta bendanya tersebut sebagai harta benda yang halal (Adami Chazawi, 2008: 115). 
Sistem pembuktian dalam delik korupsi selanjutnya diatur dalam Pasal 37 Undangundang Nomor 20 tahun 2001 yang berbunyi sebagai berikut:

1. Terdakwa mempunyai hak untuk membuktikan bahwa ia tidak melakukan tindak pidana korupsi.

2. Dalam hal terdakwa dapat membukikan bahwa ia tidak melakukan tindak pidana korupsi, maka pembuktian tersebut dipergunakan oleh pengadilan sebagai dasar untuk menyatakan bahwa dakwaan tidak terbukti.

Pasal 37 A menyebutkan:

1. Terdakwa wajib memberikan keterangan tentang seluruh harta bendanya dan harta benda istri atau suami, anak dan harta benda setiap orang atau korporasi yang diduga mempunyai hubungan dengan perkara yang didakwakan.

2. Dalam hal terdakwa tidak dapat membuktikan tentang kekayaan yang tidak seimbang dengan penghasilanya atau sumber penambahan kekayaanya, maka keterangan sebagaimana dimaksud dalam ayat (1) digunakan untuk memperkuat alat bukti yang sudah ada bahwa terdakwa telah melakukan tindak pidana korupsi.

3. Ketentuan sebagaimana dimaksud dalam ayat (1), dan ayat (2) merupakan tindak pidana atau perkara pokok sebagaimana dimaksud dalam pasal 2, Pasal 3, Pasal 4, Pasal 13, Pasal 14, Pasal 15 dan Pasal 16 Undang-Undang Nomor 31 Tahun 1999 tentang Pemberantasan Tindak Pidana Korupsi dan Pasal 5 sampai dengan Pasal 12 undang-undang ini, sehingga penuntut umum tetap berkewajiban untuk membuktikan dakwaannya.

Apabila ditilik secara intens, detail dan terperinci, ketentuan Pasal 37 dan 37 A tersebut menganut adanya dua sistem pembuktian, yaitu sistem pembuktian terbalik yang bersifat terbatas dan berimbang dan sistem negatif sebagaimana ketentuan KUHAP. Pengertian pembuktian terbalik yang bersifat terbatas dan berimbang, yakni terdakwa mempunyai hak untuk membuktikan bahwa ia tidak melakukan tindak pidana korupsi dan wajib memberikan keterangan tentang seluruh harta bendanya dan harta benda istri atau suami, anak dan harta benda setiap orang atau korporasi yang diduga mempunyai hubungan dengan perkara yang bersangkutan dan penuntut umum juga tetap berkewajiban untuk membuktikan dakwaannya.

Sebagai tindak lanjut dari pengaturan pembuktian terbalik dalam tindak pidana korupsi Pasal 37 ayat (2) Undang-undang Nomor 20 Tahun 2001 menentukan sebagai berikut:

"Dalam hal terdakwa dapat membuktikan bahwa ia tidak melakukan tindak pidana korupsi, maka pembuktian tersebut dipergunakan oleh pengadilan sebagai dasar untuk menyatakan bahwa dakwaan tidak terbukti”.

Ketentuan Pasal 37 ayat (2) inilah sebagai dasar hukum beban pembuktian terbalik hukum acara pidana korupsi. Penerapan dari ketentuan ini harus dihubungkan atau ada hubunganya dengan pasal 12B dan pasal 37A ayat (3). Hubunganya dengan pasal $12 \mathrm{~B}$, ialah bahwa sistem terbalik pada pasal 37 berlaku pada tindak pidana korupsi suap menerima gratifikasi yang nilainya Rp.10 juta atau lebih (pasal 12B ayat (1) huruf a). Sedangkan hubunganya dengan pasal 37A khususnya ayat (3), bahwa sistem terbalik menurut pasal 37 berlaku dalam hal pembuktian tentang sumber (asal) harta benda terdakwa dan lain-lain diluar perkara pokok. Pasal-pasal yang disebutkan dalam pasal 37A in casu hanyalah tindak pidana korupsi suap gratifikasi yang tidak disebut dalam pasal 37A ayat (3) tersebut.

Ketentuan pasal 37 ayat (2) berhubungan secara negatif (terbalik) dengan ketentuan mengenai seluruh harta benda terdakwa yang didakwakan dan diduga mempunyai hubungan dengan perkara korupsi yang sedang diperiksa. Apabila diteliti tentang macam- macam tindak pidana korupsi dalam perkara pokok yang menyangkut tentang harta benda terdakwa yang disebutkan secara limitatif dalam pasal 37A ayat (3), maka ternyata hanya tindak pidana korupsi suap menerima gratifikasi sebagaimana yang dimaksud dalam pasal 12B ayat (1) huruf a saja yang tidak disebut dalam pasal 37A ayat (3) tersebut (Adami Chazawi, 2008: 117).

Pada dasarnya ketentuan Pasal 37 Undang-undang Nomor 20 Tahun 2001 merupakan konsekwensi berimbang atas penerapan pembuktian terbalik terhadap terdakwa, bahwa terdakwa tetap memerlukan perlindungan hukum yang berimbang atas pelanggaran hak-hak mendasar yang berkaitan dengan asas praduga tak bersalah (presumption of innocence) dan menyalahkan diri sendiri (non self incrimination). Sedangkan Pasal 38 C mempunyai dasar pemikiran bahwa untuk memenuhi rasa keadilan masyarakat terhadap 
perilaku tindak pidana korupsi yang menyembunyikan harta benda yang diduga atau patut diduga berasal dari tindak pidana korupsi. Harta benda tersebut diketahui setelah putusan pengadilan memperoleh kekuatan hukum tetap (inkracht van gewijsde). Dengan titik tolak dimensi tersebut negara memiliki hak untuk melakukan gugatan perdata kepada terpidana atau ahli warisnya terhadap harta benda yang diperoleh sbelum putusan pengadilan memperoleh kekuatan hukum tetap (inkracht van gewijsde), baik putusan tersebut didasarkan pada undang-undang sebelum berlakunya Undangundang Nomor 31 tahun 1999 tentang Pemberantasan tindak Pidana Korupsi atau setelah berlakunya Undang-undang tersebut.

Intinya Undang-undang pemberantasan korupsi ini menegaskan bahwa melakukan gugatan perdata kepada terpidana dan atau ahli warisnya terhadap harta benda yang diperoleh sebelum putusan pengadilan memperoleh kekuatan hukum tetap (inkrach van gewijsde) tidaklah berlaku surut (retro aktif). Apabila aspek dan dimensi ini dilakukan, untuk melakukan gugatan perdata tersebut negara dapat menunjuk kuasa untuk mewakilinya (Lilik Mulyadi, 2007: 264).

Apabila dibandingkan dengan Undangundang Nomor 31 Tahun 1999, ketentuan Undang-undang Nomor 20 Tahun 2001 tidak menyebabkan terjadinya penerapan pembalikan pembuktian secara signifikan terhadap tindak pidana korupsi sebagaimana ketentuan Pasal 2 s/d Pasal 16 Undang-undang Nomor 31 Tahun 1999, tetapi hanya perubahan terhadap beban pembuktian dalam aspek gratifikasi yang berhubungan dengan suap (Pasal 12B ayat (1) huruf a), harta benda yang belum didakwakan (Pasal 38B), serta harta benda milik terpidana yang diduga atau patut diduga berasal dari tindak pidana korupsi yang belum dikenakan perampasan untuk negara yang perkara pokoknya telah memperoleh putusan berkekuatan hukum tetap (Pasal $38 \mathrm{C}$ ), kemudian adanya beban pembuktian masing-masing kepada terdakwa dan penuntut umum secara mutlak (Lilik Mulyadi, 2007: 262).

Pembuktian terbalik sebagaimana diatur dalam pasal 37 tersebut di atas berhubungan erat dengan ketentuan Pasal 12B. Jika diteliti ketentuan pasal 12B ayat (1) huruf a dan b tersebut, maka mengandung arti sebagai berikut:

Pertama, rumusan huruf a berhubungan erat dengan pasal 37. Artinya ialah tentang apa yang dimaksud beban pembuktian menurut norma ayat (1) huruf a in casu ada pada terdakwa itu objek penerapannya disebutkan dalam pasal 37.

Kedua, sistem terbalik dalam pasal 37 berlaku pada tindak pidana korupsi suap menerima gratifikasi yang nilainya Rp 10 juta atau lebih

Ketiga, tindak pidana korupsi suap menerima gratifikasi yang nilainya kurang dari Rp 10 juta, beban pembuktian ada pada Jaksa Penuntut Umum.

Keempat, unsur-unsur tindak pidana korupsi suap menerima gratifikasi, yaitu: (1) pegawai negeri atau penyelenggara negara; (2) menerima gratifikasi; (3) berhubungan dengan jabatanya dan; (4) berlawanan dengan kewajiban atau tugasnya (Adami Chazawi, 2008: 118).

Dengan memperhatikan perkembangan tindak pidana korupsi, baik dari sisi kuantitas maupun dari sisi kualitas, dan setelah mengkaji secara mendalam, tidaklah berlebihan jika dikatakan bahwa korupsi di Indonesia bukan merupakan kejahatan biasa (ordinary crimes) melainkan sudah merupakan kejahatan yang sangat luar biasa (extra ordinary crimes). Selanjutnya, jika dikaji dari sisi akibat atau dampak negatif yang sangat merusak tatanan kehidupan bangsa Indonesia sejak pemerintahan Orde Baru sampai saat ini, jelas bahwa perbuatan korupsi merupakan perampasan hak ekonomi dan hak sosial rakyat Indonesia (Lilik Mulyadi, 2007: 251).

Konsekuensi logis bahwa tindak pidana korupsi merupakan extra ordinary crimes, diperlukan penanggulan dari aspek yuridis yang luar biasa (extra ordinary enforcement). Salah satu langkah komprehensif yang dapat dilakukan dalam sistem peradilan Pidana Indonesia adalah melalui sistem pembuktian yang relatif lebih memadai yaitu diperlukan adanya pembuktian terbalik atau pembalikan beban pembuktian (Lilik Mulyadi, 2007: 253).

Ketentuan Pasal 37 Undang-undang Nomor 20 Tahun 2001 menurut penjelasanya merupakan konsekwensi berimbang atas penerapan pembuktian terbalik terhadap terdakwa, bahwa terdakwa tetap memerlukan perlindungan hukum yang berimbang atas pelanggaran hak-hak mendasar yang berkaitan dengan asas praduga tak bersalah (presumption of innocence) dan menyalahkan diri sendiri (non selfincrimination). Konsekuensi logis dimensi demikian dari ketentuan Pasal 37 ayat (2) Undang-undang Nomor 20 Tahun 2001 tidak menganut sistem pembuktian secara negatif menurut undang-undang (negatif wettelijk). 
Manifestasi dan implementasi beban pembuktian pada jaksa Penuntut Umum ini merupakan hak /terdakwa berupa presumption of innocence yang merupakan aktualisasi asas non self-incrimination yaitu hak tersangka/terdakwa untuk tidak mempersalahkan diri sindiri. Akan tetapi untuk tindak pidana korupsi, diterapkan sistem pembuktian terbalik guna mewujudkan keadilan masyarakat. Konsekuensi logis dengan diterapkannya sistem pembuktian terbaik yang bersifat murni atau absolute/mutlak adalah diterapkanya asas praduga bersalah (presumption of guilt), dalam arti seseorang dianggap bersalah telah melakukan suatu tindak pidana korupsi sampai dengan yang bersangkutan dapat membuktikan dirinya tidak bersalah melakukan tindak pidana korupsi. Secara teoritis jika memang diterapkan sistem pembuktian terbalik yang bersifat murni atau absolut, maka tidak diperlukan dan/atau diwajibkan Jaksa Penuntut Umum untuk membuktikan kesalahan terdakwa dalam melakukan tindak pidana korupsi (Lilik Mulyadi, 2007: 267).

Jika dilihat dari aspek perlindungan terhadap terdakwa penerapan sistem pembuktian terbalik dalam tindak pidana korupsi merupakan pelangggaran terhadap asas praduga tak bersalah. Dalam sistem pembuktian terbalik hakim berangkat dari praduga bahwa terdakwa telah bersalah melakukan tindak pidana korupsi sampai terdakwa bisa membuktikan sebaliknya. Dalam sistem pembuktian seperti tersebut di atas, tampak bahwa hak-hak terdakwa tidak dijamin, bahkan dilanggar. Padahal menurut Pasal 183 KUHAP "Hakim tidak boleh menjatuhkan putusan pidana kepada seseorang kecuali apabila dengan sekurang-kurangnya dua alat bukti yang sah ia memperoleh keyakinan bahwa suatu tindak pidana benar-benar terjadi, dan bahwa terdakwalah yang bersalah melakukanya".

Uraian di atas menunjukkan bahwa dengan diterapkannya beban pembuktian terbaik secara murni atau absolut, secara teorites, normative dan praktis dipersyaratkan harus ada keyakinan Jaksa Penuntut Umum bahwa terdakwa melalui alat bukti dan barang bukti yang ada secara limitatif telah benar melakukan tindak pidana korupsi dan bila hal ini diabaikan akan berakibat bahwa terdakwa berhasil membuktikan dirinya tidak bersalah melakukan tindak pidana korupsi sehingga akan mengakibatkan terdakwa diputus bebas (vrijspraak) oleh hakim di depan sidang pengadilan umum maupun pengadilan ad hoc tindak pidana korupsi.
Dalam pengertian yang sempit, sistem pembuktian mengacu pada ketentuan tentang standar-standar dalam hal membuktikan sesuatu in casu kesalahan terdakwa melakukan tindak pidana yang didakwakan, seperti dalam sistem negatif menurut undang-undang yang terbatas (negatief wettelijk) sebagaimana diatur dalam Pasal 183 KUHAP. Standar untuk menyatakan terbukti atau tidaknya kesalahan terdakwa ialah pertama, harus ada atau berdasarkan sekurangkurangnya dua alat bukti yang sah; kedua, dari dua alat bukti itu hakim memperoleh keyakinan terjadi tindak pidana dan terdakwa bersalah melakukannya. Sedangkan sistem pembebanan pembuktian mengacu pada pihak mana yang dibebani kewajiban membuktikan dan hal apa yang harus di buktikan, juga mengenai standar pengukur untuk menentukan terbukti tindakanya (Adami Chazawi, 2008: 109).

Berpijak dari pengertian sistem pembuktian dan sistem pembebanan pembuktian tersebut di atas, maka kekhususan dalam hukum acara pidana korupsi lebih mengacu pada sistem pembebanan pembuktian (burden of proof). Pada dasarnya sistem pembuktiannya sama dengan memberlakukan Pasal 183 KUHAP, khususnya bagi hakim dalam menilai alat-alat bukti. Standar yang harus diturut untuk menyatakan terbukti tidaknya terdakwa melakukan tindak pidana yang didakwakan tetap terikat pada ketentuan Pasal 183 KUHAP. Ini merupakan ketentuan asas pokok atau fondasi hukum pembuktian acara pidana yang tidak dengan mudah disimpangi oleh hukum pembuktian acara pidana khusus, jadi sungguh berbeda dengan apa yang sering didengar bahwa sistem pembuktian dalam tindak pidana korupsi telah menganut sistem terbalik sesungguhnya yang dimaksud adalah sistem pembebanan pembuktian terbalik (Adami Chazawi, 2008: 110).

Meskipun penerapan sistem pembuktian terbalik bertentangan dengan asas praduga tak bersalah yang diatur dalam KUHAP, namun dalam hal ini berlaku asas lex specialis derogat lex generalis, selain itu penerapan pembuktian terbalik merupakan salah satu cara yang dapat ditempuh untuk memberantas tindak pidana korupsi yang telah mengakar di Indonesia. Penerapan pembuktian terbalik terhadap tindak pidana korupsi memang di satu sisi merugikan terdakwa, karena hak-haknya kurang terlindungi, akan tetapi di sisi yang lain ini akan membawa kemanfaatan yang lebih besar bagi banyak orang, karena dapat mengurangi tindak pidana korupsi yang telah merugikan keungan negara. 


\section{E. Simpulan}

Berdasarkan hasil penenlitian dan pembahasan, maka penulis disimpulkan sebagai berikut:

Pertama, sistem pembuktian terbalik dalam Undang-undang tindak pidana korupsi diatur secara limitatif dalam Pasal 12B ayat (1), Pasal 37, Pasal 37A, Pasal 38A dan Pasal 38B Undang-undang Nomor 20 Tahun 2001 tentang perubahan Undang-undang Nomor 31 Tahun 1999 tentang pemberantasan tindak pidana korupsi.

Kedua, Penerapan sistem pembuktian terbalik terhadap tindak pidana korupsi merupakan ketentuan yang bersifat khusus (lex specialis) dalam hukum acara pidana. Penerapan pembuktian terbalik merupakan salah satu cara untuk menganggulangi tindak pidana korupsi yang merupakan kejahatan luar biasa. Ketentuan ini merupakan penyimpangan dalam sistem pembuktian konvensional sebagaimana diatur oleh KUHAP, sehingga dalam hal ini berlaku asas lex specialis derogat lex generalis.

\section{F. Saran}

Berdasarkan kesimpulan di atas, penulis dapat memberikan saran sebagai berikut:

1. Agar penerapan pembuktian terbalik dapat dilaksanakan secara maksimal, kepada pembentuk undang-undang, dalam merumuskan suatu norma hukum dalam hal ini ketentuan tentang pembuktian terbalik harus dirumuskan secara jelas dan tidak bersifat ambigu, dan multi tafsir sehingga dalam implementasinya dapat dilaksanakan secara sempurna karena tidak ada penafsiran yang berbeda.

2. Untuk para praktisi hukum (polisi, jaksa, hakim dan advokat) dalam memahami ketentuan perundang-undangan, khususnya undang-undang pemberantasan tindak pidana korupsi, tidak hanya melihat teks undangundang saja, akan tetapi lebih melihat pada semangat pemberatasan korupsinya, sehingga dalam menegakkan hukum tidak hanya menekankan segi kepastian hukumnya semata, akan tetapi lebih mengedepankan keadilan masyarakat. 


\section{Daftar Pustaka}

Adami Chazawi. 2008. Hukum Pembuktian Tindak Pidana Korupsi. Bandung: Alumni.

Barda Nawawi Arif. 2000. Pencegahan dan Penanggulangan Kejahatan. Jakarta: Departemen Hukum dan Perundang-undangan.

Burhan Bungin. 2001. Metodologi Penelitian Sosial, Format-format Kuantitatif-kualitatif. Surabaya: Airlangga University Press.

Djoko Sumaryanto. 2009. Pembalikan Beban Pembuktian Tindak Pidana Korupsi dalam rangka Pengembalian Kerugian Keuangan Negara. Jakarta: Prestasi Pustaka.

Darwan Prints. 2002. Pemberantasan Tindak Pidana Korupsi. Bandung: PT. Citra Aditya.

Evi Hartanti. 2009. Tindak Pidana Korupsi. Jakarta: Sinar Grafika.

Hari Sasangka. 2003. Hukum Pembuktian dalam Acara Pidana. Bandung: Mandar Maju.

Imam Suprayogo \&Tobroni MS. 2003. Metodologi Penelitian Sosial Agama. Bandung: Remaja Rosda Karya.

Johnny Ibrahim. 2011. Teori\&Metodologi Penelitian Hukum Normatif. Malang: Banyu Media.

K. Wantjik Saleh. 1983. Tindak Pidana Korupsi dan Suap. Jakarta: Ghalia Indonesia.

Lilik Mulyadi. 2007. Tindak Pidana Korupsi di Indonesia, Normatif, Teoritis, Praktik dan Masalahnya. Bandung: PT. Alumni.

Martiman Prodjohamidjojo. 1983. Sistem Pembuktian dan Alat Bukti. Jakarta: Ghalia Indonesia.

Mandar Maju.

M. Yahya Harahap. 2005. Pembahasan Permasalahan dan Penerapan KUHAP, Pemeriksaan Sidang Pengadilan, Banding, Kasasi dan Peninjauan Kembali. Jakarta: Sinar Grafika.

Ninik Mariyanti. 1986. "Suatu Tinjauan tentang Usaha Pemberantasan Tindak Pidana Korupsi”, dalam Andi Hamzah (ed). Bunga Rampai Hukum Pidana dan Acara Pidana. Jakarta: Ghalia Indonesia.

Petter Mahmud Marzuki. 2005. Penelitian Hukum. Jakarta: Kencana.

Subekti. 2005. Hukum Pembuktian. Jakarta: Pradniya Paramita. 